words was a lower court case in which the note upon which the plaintiff was suing contained two promises to pay. This was held to bring the note within the Uniform Written Obligations Act. Such a result, while it may not be undesirable in this case, does reveal the possibility of overly loose interpretation of the meaning of the act. For if two promises to do the same thing constitute an expression of an intention to be bound, why does not a single promise serve the same purpose? The result of further interpretation of this sort might well be to make all written promises binding.

\title{
ESTOPPEL OF THE CONDITIONAL SELLER IN LLINOIS, FOR DELAY AFTER DEFAULT BY THE BUYER
}

After Sherer-Gillette Co. v. Long, , which held that the buyer's possession under a conditional sale contràct was not ground for estopping the seller as against third persons claiming through the buyer, the validity of the seller's reserved title in Illinois was regarded as unquestionable. The decision abruptly reversed the former practice of protecting transferees and creditors of the buyer, and gave apparently unrestricted protection to the seller.2

Three decisions of the Illinois Appellate Courts since the Sherer-Gillette case, however, have imposed restrictions upon the seller's reserved title. In each case the seller had delayed "unreasonably" in asserting his rights after a default by the buyer on the last ${ }^{3}$ installment. In one case the seller was estopped by a lien creditor of the buyer who attached after the default.4 In two cases the estoppel protected bona fide purchasers who bought the property after the default. ${ }^{5}$ The

in which the defendant delivered to the plaintiff an unsealed instrument purporting to give the plaintiff for a consideration of one dollar, an option to purchase land. Although the dollar was never paid, it was held that the defendant was bound. In 79 U. Pa. Law Rev. II39 (193I) it is suggested that the Uniform Written Obligations Act, which was already operative in Pennsylvania, may have influenced this decision. Perhaps it also indicates that the Uniform Written Obligations Act is the logical consequence of the suggestion of Prof. Decker (I Ill. Law Bull. I 72) that the recital of a nominal consideration should take the place of the seal by an extension of Justice Story's opinion in Lawrence v. McCalmot. See supra note I2.

${ }^{2} 3$ I8 IIl. 432, 149 N.E. 225 (1925). The decision changed the existing law and was based on $\S \S 2 x$ and 23 of the Uniform Sales Act. For a criticism of Sherer-Gillette v. Long, see 20 IIl. L. Rev. 709 ( 1926 ). The Pennsylvania Supreme Court held that $\$ \$ 20$ and 23 did not affect the rights of sellers and third persons. See Anchor Concrete Co. v. Pa. Brick and Tile Co., 292 Pa. 86, 90, I40 Atl. 766, 767 (1928).

2 At common law, in Tllinois, Maryland, and Pennsylvania, the reserved title of a conditional seller was invalid as against bona fide purchasers and lien creditors of the buyer in possession. See Bogert, Commentaries on Conditional Sales, Unif. Laws Annotated, Vol. 2A, 58 (I924).

3 The seller has not been estopped for a delay in an intermediate, as distinguished from a final payment. Silverthorne v. Chapman, 259 Ill. App. 289 (1930).

4 Haines v. Doss, 269 Ill. App. 179 (1933).

5 Provus Bros. v. Sjolander, 273 IIl. App. 374 (1934); Dayton Scale Co. v. General Market House, 248 IIl. App. 279 ( $x 929$ ). By reversing on another ground, the Illinois Supreme Court impliedly recognized the validity of estoppel doctrine, 335 Ill. 342 , I67 N.E. roo (1929). 
decisions have rested upon analogy to the practice of cutting off the recorded lien of a chattel-mortgagee who has delayed after default by the mortgagor on the last payment. ${ }^{6}$ Whether the doctrine will be generally accepted is still doubtful. Not all divisions of the Appellate Court have expressly approved it; and delays of seven days ${ }^{7}$ and of seven months ${ }^{8}$ have been held insufficient.

In other jurisdictions where the conditional sale was valid without benefit of a recording act the seller's delay caused postponement of his interest to persons claiming from the buyer. Some decisions appear to rest upon laches. ${ }^{9}$ One held the reserved interest invalid after default because it was secret. ${ }^{.0}$ The Delaware courts attempted to set up a definite period of permitted delay, ${ }^{\text {II }}$ but subsequently adopted a flexible standard of reasonableness..$^{\text {I2 }}$ It has not been made clear in the cases whether the defeasance was based upon delay before or after the transfer, or both. ${ }^{13}$ But in the diversity of all the decisions, not one has been based unequivocally on estoppel.

The argument for estopping the seller can be given a substantial basis on the ground that his delay lengthens the time during which the buyer can deceive strangers and makes possible their damage. Estoppel, however, requires more than inaction or delay, unless the party estopped had an opportunity to prevent reliance by third persons. ${ }^{14}$ Since the seller had no such opportunity his estoppel can rest only on the transfer of possession, to the conditional buyer, which under the Sherer-Gillette case is insufficient. Moreover, since the buyer had no knowl-

${ }^{6}$ Reed v. Eames, I9 Ill. 594 ( 1858 ); Shannon v. Wolf, I73 Ill. 253, 50 N.E. 682 (I898). The estoppel of the mortgagee is an anomaly. Illinois statutes, since I8rg, have required that chattel mortgages and the mortgagee's discharge be recorded. Smith-Hurd's III. Ann. Stat. c. $95, \S 9$ (r934). Thus the true state of the title can be determined by reference to the records. The law in Illinois is contrary to the great weight of authority. See 2 Jones, Chattel Mortgages and Conditional Sales $\$ \$ 369,370$ (Bower's ed. 1933 ). But the delay does not render the mortgage invalid as between the parties or as against a purchaser with actual notice. Sandheimer v. Graeson, 172 Ill. I74, 50 N.E. I74 (1898).

7 Standard Computing Scale Co. v. Dombrowski, 257 Ill. App. 409 (I930).

${ }^{8}$ American Type Founders Co. v. Metrop. Credit and Discount Co., 27 I Ill. App. 179 (1933). Although the court sought to distinguish Haines v. Doss, supra note 5, no distinction can be made between the two cases. The court, in effect, repudiated Haines v. Doss by quoting with approval from a recent federal case holding that a conditional seller may assert his rights against the buyer's receiver in bankruptcy within any time short of the Statute of Limitations. See In re Steiner's Improved Dye Works, 44 F. (2d) 555 (I930). This case, however, is not relevant in a controversy between the seller and a third party because the receiver in bankruptcy acquires only the buyer's rights.

9 Owenby v. Swann, 59 S.W. 378 (Tenn. 1900); Robbins v. Phillips, 68 Mo. roo (1878); see also Sanders v. Keber, 28 Ohio St. 630 (1876).

ro Matthews v. Smith, 8 Houst. (Del.) 22, 3I Atl. 879 (I88I).

Ir See Matthews v. Smith, supra note ro.

${ }^{22}$ Linger v. Abbott, 3 Boyce (Del.) 4I3, 84 Atl. 95० (I9I 2).

33 See Matthews v. Smith, supra note Io.

${ }^{14}$ Macomber v. Kinney, Ir4 Minn. I46, I28 N.W. roor; Bigelow, Estoppel 503 (r913). 
edge of default or delay, it is impossible for him to prove actual reliance. A further difficulty with the estoppel theory, as it has been applied, is that no distinction has been made between delay before and delay after the transfer. ${ }^{15}$ Yet if the seller's misleading conduct is, in reality, the reason for penalizing him, it is only the conduct before the transfer which could possibly have damaged the sub-purchaser. These considerations throw doubt upon the theoretical soundness of this method of protecting third persons.

Waiver of title has been suggested as a more reasonable method of cutting off the seller. ${ }^{x^{6}}$ While this overcomes the objection of lack of reasonable reliance upon the conditional buyer's possession, mere delay, without more, is a slender foundation for inferring an intention to relinquish substantial rights. ${ }^{x 7}$ True waiver would cut off the seller's interest even as against the buyer; but in the chattel mortgage cases the court has refused to give this effect to delay. ${ }^{18}$ If judicial limitations upon Sherer-Gillette Co. v. Long are desirable, perhaps a better argument is found in the cases of constructive fraud, resting upon the seller's retention of possession after an absolute sale. ${ }^{19}$ The general use of the conditional sale in honest transactions, however, makes it difficult to infer fraud from a delay after default.

Before the Uniform Sales Act was passed, conditional sales were held invalid in Tllinois. ${ }^{20}$ The present tendency to limit the reserved title may be attributed to the strength of the old rule. Judicial attempts to deal with the problem upon any basis, however, would not correct the present uncertainty of the law, for the reasonableness of a given delay would always depend upon particular facts. The embarking of the courts upon the hazardous task of determining such questions suggests that the need for some adequate protective device is urgent. The recording system of the Uniform Conditional Sales Act ${ }^{25}$ would enable both sellers and persons dealing with buyers to protect themselves. Passage of this or a similar act is the only remedy for the situation disclosed by the cases since Sherer-Gillette Co. v. Long. ${ }^{22}$

${ }^{35}$ Provus Bros. v. Sjolander, supra note 5; cf. Standard Computing Scales Co. v. Dombrowski, supra note 7 , at 4 III.

${ }^{36}$ See 25 Ill. L. Rev. 218, 219 (I930); 22 Ill. Bar J. 266, 267 (I934).

I7 See 2 Williston, Contracts $\$ 678$ (I920). $\quad{ }^{18}$ See Sandheimer v. Graeson, supra note 6.

19 See I Williston, Sales $\$ \S 35$ I, 352 (I924). $\quad 20$ Supra note 2.

2x See Bogert, Uniform Conditional Sales Act, 3 Cornell L. Q. I (Igr8).

${ }^{22} 3$ I8 Ill. 432, I49 N.E. 225 (I925). In National Bank of the Republic v. Wells-Jackson Corp., 358 Ill. 356 , I93 N.E. 2 I 5 (I934), the Illinois Supreme Court refused to estop a conditional seller in favor of the lessor of the building, who re-entered after the tenant had defaulted in rent. The decision, however, was limited to a consideration of the lessor's right to regard the installed property as belonging to the freehold, and does not seem to control the cases previously decided by the Appellate Court. 